CHRISTY EMILIO IOANNIDOU

The Association of Historical

Studies KORYVANTES

Athens, Greece

E-mail: perialos1@gmail.com
904:359»637»(38)

COBISS.SR-ID 272003084

Original research article

Received: October $25^{\text {th }} 2018$

Accepted: October $30^{\text {th }} 2018$

\title{
HELLENIC MARINE FORCES IN LATE BRONZE AGE GREECE
}

\begin{abstract}
Bronze Age excavation finds offer a great number of information relating the naval architecture of Greek ships. Unfortunately depictions with war character are quite limited. In addition, the paucity of naval battles on illustrations and texts raise many difficulties to the study of naval warfare. Warriors on board, who consisted a primitive type of marine corps of Late Bronze Age Greece, offers an obstructive but very exiting area for research.
\end{abstract}

\section{KEYWORDS: GREEK SHIPS, MARINE FORCES, LATE BRONZE AGE GREECE.}

\section{MARINES, EPIBATAI ('EПIBATAI)}

The archaeological evidence on the Bronze Age Naval Warfare provides us specific information on the nature of the sea-conflicts. The campaigns of Attarsiya (1400-1220 BC), as well as his conflict with Madduwatta, the Hittite vassal, represent the first recorded Mycenaean Greek military activity on the Anatolian mainland (Kelder $2005,154)$. The already six recorded military activities of the Mycenaeans in Anatolia, presume extremely strong naval powers which would dominate in the Aegean sea and able to disembark numerous warriors for such land-campaigns. Although the already recorded Ahhiyawan enterprises in Anatolia do not provide us information on any naval battle, it is a strong indication that the Mycenaeans were already familiar with naval raid-operations and naval warfare. Based on the limited Aegean potteries and frescoes, but mostly on the Medinet Habu monument (Nelson 1943) we can see that the typical naval battle of those times in Eastern Mediteranean basin included close-quarters fights on decks and the use of mis- sile weapons (Johnston 1985, 16). So, the role of ship commander and his manoeuvres, as we know from the glorious era of trireme (Ioannidou 2016), was set apart. The on-board warriors were the ones who would attack on the enemy ship, trying to kill the enemy crew and capture the enemy boat, which would be considered as an extremely expensive and valuable trophy. These men could achieve strong and far range shots (Bakas, 2014, 10-19) against mobile targets (crew and sails). When the ships would get touch each other they would use small range weapons, as close-quarters fights were taking place on decks.

Leaving apart the occasions of land-fighter who used ships to engage in the battle field, we realize how difficult could be a task for a marine. At least a rudimentary training or a simple range practice on a deck could existed but there no documents or depictions to prove this. Contrary to Homer's lack of information about naval battles, we find several descriptions in his epics of warriors taking part on sea conflicts and landing operations. But concerning marines' training, the information we have are much later (Thucydides, 
7.63, 7.67, Polyainos, Strategemata, 2.7, Arrian, Alexander Anabasis, 7.23). We can assume with reasonably certainty that a similar training of Classical period (Ioannidou 2016, 52-54, 59-63, 69-72 and Charles 1948, 181-188) could exist in Late Bronze Age too.

One may understand the difficulty of a land-fighter to stand on a tossed and unstable ship during a naval battle, to maintain his balance, to shoot from a distance and to locate his target simultaneously. If one of these warriors slips on the deck he will lose the target, maximize ship's instability and may injure himself and others as well. Due to lack of descriptions, "marine" of that period is common defined as a land-fighter on shipboard who knows also how to use the oars. Thucydides $(7,67)$, much later, will define how dangerous will be to use land-fighters as marines. Was really possible for the Late Bronge Age warriors to ignore the importance of training?

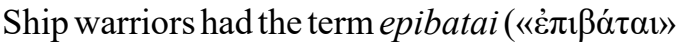

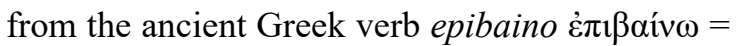
board a ship, Ioannidou 2014) though they were not "passengers" like the modern Greek term means. We find the verb epibaino from the Homeric Epics (Hom. Il, 8, 512 [boarding on a ship] and Hom. Od, 12, 434 [standing on the ship]) but the word epibatai is a term of classic Greece. Hesychius describes the term:

he who is not an oarsmen but who fights on board

«ó $\mu \grave{\eta} \kappa \omega \pi \eta \lambda \lambda \dot{\alpha} \tau \eta \varsigma, \dot{\alpha} \lambda \lambda \grave{\alpha} \pi \lambda \dot{\varepsilon} \omega v \mu \alpha \chi \eta \tau \dot{\zeta} \varsigma »$ (Hes-

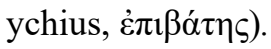

Therefore, it is not dairy to conclude that ancient Greek epibatai were like today marines. They consisted, in a way, a primitive brunch of Army Forces of a city or country who intended for amphibious operations with the use of infantry and ships. Because of their naval training we could say that they are not always land-fighters who happened to be on warships but many times consisted a part of the total naval establishment of the nation.

\section{EQUIPMENT}

The typical marine armor equipment should have followed the needs of the naval warfare pattern of the deck-assault: Helmets, body armor, shields, javelins, swords, spears. Various depictions show marines wearing heavy armament (for example Fig. 3) which for such battlefield (for example tossed and slipping deck) should be not functional but dangerous. A jump into the sea of such a warrior would cause his drown. Even in land battles, large shields approved malfunctioned as vividly describes Homer (Hom. Il, 6, $118 \mathrm{Hec}-$ tor's shield and 15, 645 the shield of Perifetes of Mycenae). Perhaps this emblematic armament was for leaders, high range officers or the artist wanted to emphasize the war element. It is more logical a marine of LH period to prefer the absence or the use of light armament (Ioannidou 2016, 52-54). After all there are plenty of these examples in depictions. We can assume that the marine would use a slash cut sword rather than a rapier sword. As Tarlea notes, the rapiers, through their shape and qualities, indicate a very special kind of combat where a lot of space was needed. The narrow cutting-edges and the high midrib make them totally unsuited for lateral blows, which would have only a negligible effect. Even more, the attempt of hitting laterally could prove risky, because it is almost certain that the sword wouldn't survive the shock. The ample lateral blows of the slashing swords. We can assume that the fighting with a rapier is closer to the contemporary idea of a duel than the fight with a slashing sword. The opponents must show aptitudes and abilities most probably gained after years of trainings and successful fights. Very possibly exactly these duelist qualities are in the foreground. The ability proved by the fighter when he manages to send a fatal blow to the enemy must be doubled by the ability of protecting himself in front of his counterstrikes (Tarlea 2005, 132). A slashing sword would be more suitable in this kind of warfare as the marine would need to perform quick front and lateral cuts in an unstable plat- 
form. The slashing swords, through their nature, tend to have no or very low midrib and to be stouter and heavier. Only the cutting-edges being used, it is expected the blows come mostly from the lateral. On the one hand, this leads to the placement of the balance point to the sword's tip, in order to increase the force of the blow.

The purpose of the use of bow, in tactical level, was to disturb the enemy's crew from a distance and to support the heavy armoured fighters during their engage with the enemies on board. Its presence should be necessary in every recruit of naval missions. Philoctetes' ships were manned by fifty oarsmen well trained in bow (Hom. Il, 2, 720). Archers are mentioned using poisoned arrows, common in ancient history, which would increase the effectiveness of archery at sea as much as on land (Wood 2012, $39 \&$ Mayor 2006, 6280 ). Despite the numerous depictions of archers in the land there are no figures of archers on a warship except those of Geometrical period and after. That, of course, could not support the opinion of the absence of such important corp. However on a shred of LH IIIC founded in ancient Kynos (Fig. 5) there is a warrior who his body posture looks like an archer (Wachsmann 2009, 137). He is standing in the ship's bow with one hand stretched and the other bended as archers doing when they bend their composite bow which was in use in LH period (Brecoulaki 2008, 376 \& Bakas 2016, 9-15). But at this point the shred is broken and ship's stem is in front of the stretched hand. As a result ship's stem and broken part cover hand, bow and arrow. This not allow us to have a clear picture of an archer on a ship even if a small mark looks like the tip of a bow. Hoping that someday the piece of that shred will be find we will be in such a pleasure position to have the first archer/ marine depiction on ship of LH period. However the Medinet Habu monument portrays a large number of Egyptian archers on board shooting on the Sea - people crew (Nelson 1943, 46-47). Even the fact that the monument describes a conflict that can be indirectly been associated with Aege- an cultures (Kramer-Hajos 2016, 159), it can be a strong argument that the contemporary Egyptians were using mass numbers of archers on their ships and this could be a common battle tactic among the east mediteranean Bronze age cultures.

Concerning the slingers, their presence was often in all Helladic territory from the Early Helladic but only for hunting of for protection, as far. As an organized corps unit we find them at Middle Helladic (2100-1600 BC) (Everson 2006, 52 and Grguric 2005, 6).

Slingshots were made of shaped stone or unfired claim. From 1300 BC slingshots were made from lead. Characteristic samples are founded in Knossos and Cyprus. There are not any depictions of slingers on ships until now. Although Vutiropoulos (Vutiropulos 1991, 283) believe that the first depictions of wrecked slingers are in the north Miniature Frieze from Akrotiri, Thera (Fig.6), opinion which could be seriously supported. If these bodies are slingers then the black objects floating in the water (a rectangular object with strap and an amorphous blob) could be leather bags for carrying slings and slingshots.

\section{SOME WORDS ABOUT THE DECK ON LATE BRONZE AGE SHIPS}

Even if warships are out of scope of this paper we should see briefly an issue that pops out when examining depictions from this period. If we focus on ship decks and the way that marines postured upon them we realize that most of warships of that era were not undecked but they do had a deck. Not fully decked like Cimon's triremes (Plut. Cim. 12, 2) but a partly deck existed and protected oarsmen's head (Dakoronia 1999, 123; Wedde 1999, 515; Kirk 1949, 117, 127; Marinatos 1933, 220; Wachsmann 2009, 142). As Dakoronia correctly wrote about marines on Kynos fleet: "It would not be possible for them to fight from the hull of the ship, among banks for the oarsmen, mast, sail and other provisions. Only the helmsman stands 


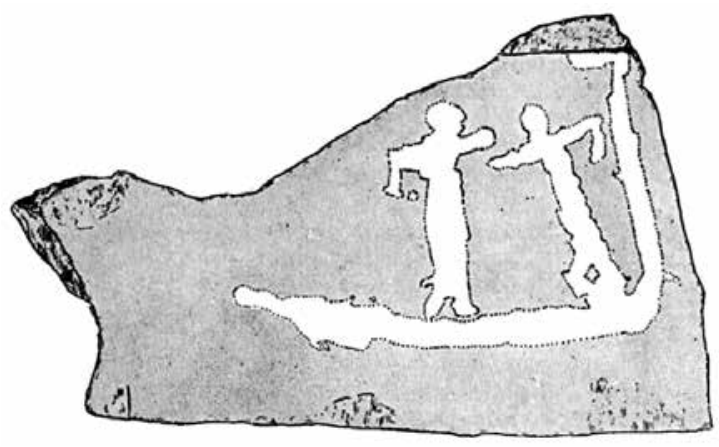

Fig. 1 Stone from Naxos (2300-2100/2000 BC).

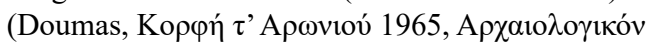
$\Delta \varepsilon \lambda \tau$ íov 20: 53).

somewhere deeper and this supports the theory that along both sides of the ships ran side decks, joining bow and stern, which were supported on struts or stanchions, also used us thole-pins" (Dakoronia 1999, 123). Maybe this current fallacy about the un-decked warships arose from a rough translation of Thucydides text.

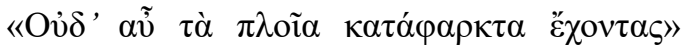
(Thuc.1, 10) which means that their ships were

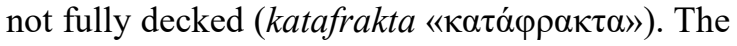

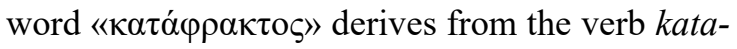

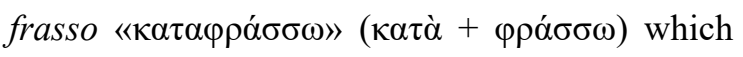
means to cover, to close. So, warships of Bronze

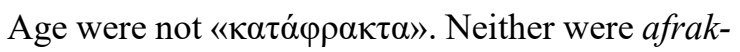

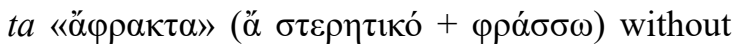
any deck. In Greek grammar " $\alpha$ " is a negative prefixe like "un" in English grammar (un-decked ship). So if a ship is not fully decked katafrakto does not mean that is without deck afrakto but partly or semi-deck. Thucydides, after all, used specific words to describe precisely the exact meaning of every term, even in past, unknown times for him like LH period.

\section{LOOKING ON DEPICTIONS}

Searching the first depiction from finds with figures of marines we should close off from our research those who present men without weapons or people that their attitude is not clear if

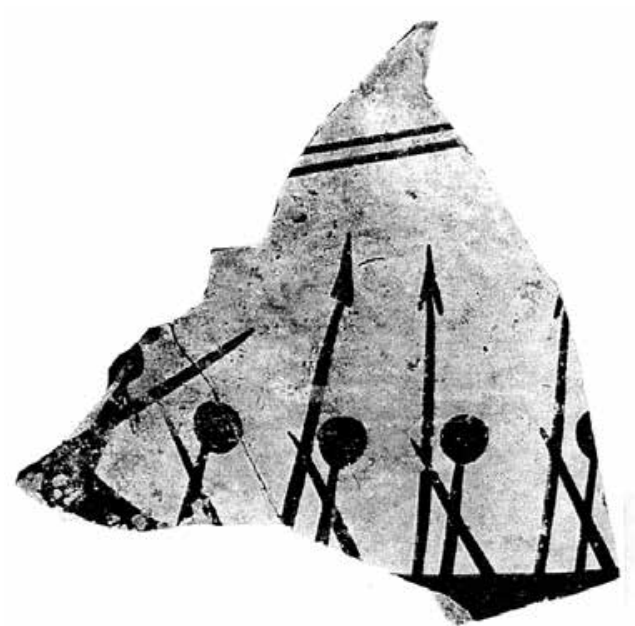

Fig. 2 Shred of Kolona, Aegina from Middle Helladic period $(1700 \mathrm{BC})$

they are fighting or not. For example on a piece of a hammered rock-carving stone (Fig. 1) from Korfi Aroniou in Naxos island, (Early Cycladic III), there are two figures of men, who stands on a ship and looks like they are violently involved. No weapons are visible1 and that raise doubts if the scene depicts a military act or a duel between crewmembers. According to Doumas the scene presents works on a ship and if we see a duel then this could have as reason an ownership matter or a simple quarrel that happened quite enough between crewmembers, especially during bored, long distance trips (Doumas 1965, 53).

Considering above perhaps the first depiction of marines is the one on a shred of Kolona, Aegina (Fig. 2) from Middle Helladic period. In this we can see clearly the crew (oarsmen or marines) that they are holding long spears and the helmsman who works a single quarter rudder. The appearance of helmsman testifies that the ship is on the sea and either is approaching another ship or a coast with marines ready for landing. Others suggest that this concern a pirate action (Basch 1991, 48).

A very interesting depiction came from Mycenaean Late Helladic IIIB krater from Enkomi (Fig. 3 ) shows men standing in the same manner, facing each other in pairs (Wachsmann 2009, 141). Five

1 Except in other pieces of the same excavation where we can see scenes of hunting animals. 


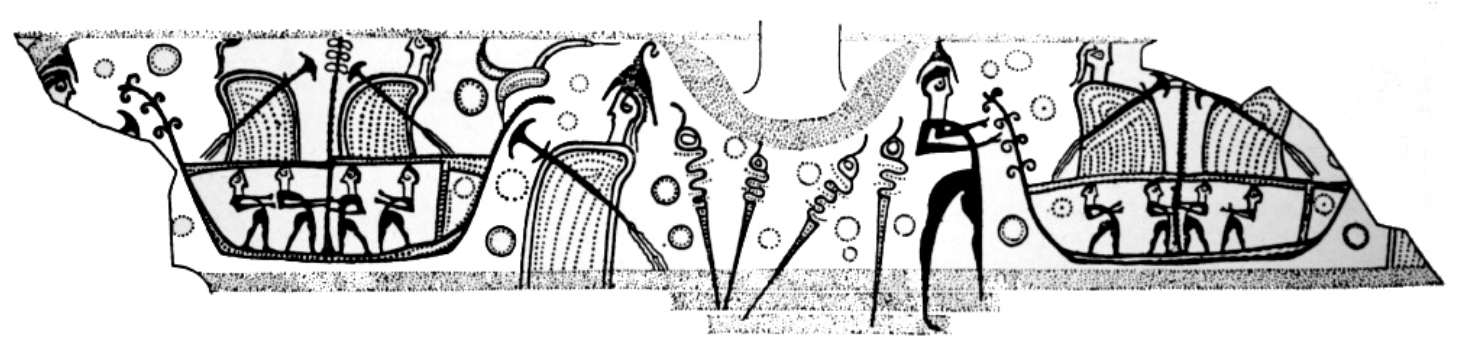

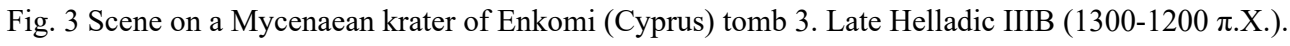

(Sjogvist 1940: fig. 20. 3).

and half men are heavy armed while the rest 8 are naked or light armed.

Heavy armed warriors are wearing helmets and holding tower shields which their riveting suggests that these shields were curved like half cylinder "in order to protect the warrior as much as possible" (Lorimer 1950, 140, fig. 2). This type of shield is similar to Homeric "sakos" (Ajax's shield) (Hom. II, 7.219-225, 7.232-247) but laden with ornaments. A so valuable shield, as it appears, perhaps corresponded to high rank officers.

They also carry swords in scabbards which their ends have wavy lines. Similarities with the warriors of Miniature Frieze, appeared as well.

The vessels seem like being fully decked (Wachsmann 2009, 142), while under decks men are fighting each other.
An obvious proof and scenes of naval battle from Mycenaean period, or the oldest depiction of sea conflict in the Aegean area maybe appears in a LH IIIC Middle krater from Pyrgos Livanaton, the Homeric Kynos (Dakoronia, 1999, 121) (Fig. 4). Men figures are clearly marines. They are holding shield and spear and looks ready for an assault or a close-in combat on decks. According to Basch maybe this is a depiction of a piracy act (Basch, 1996, 32-33). The ships are of the same type.

The figure of the helmsman testifies the sea-conflict while the dead body suggests the human loss which follows after naval battle.

All marines wear "hedgehog type" helmet. This, less known construction, helmet is quite common in that period. It is believed that was made from hide of goat, ox or from actual hedge-

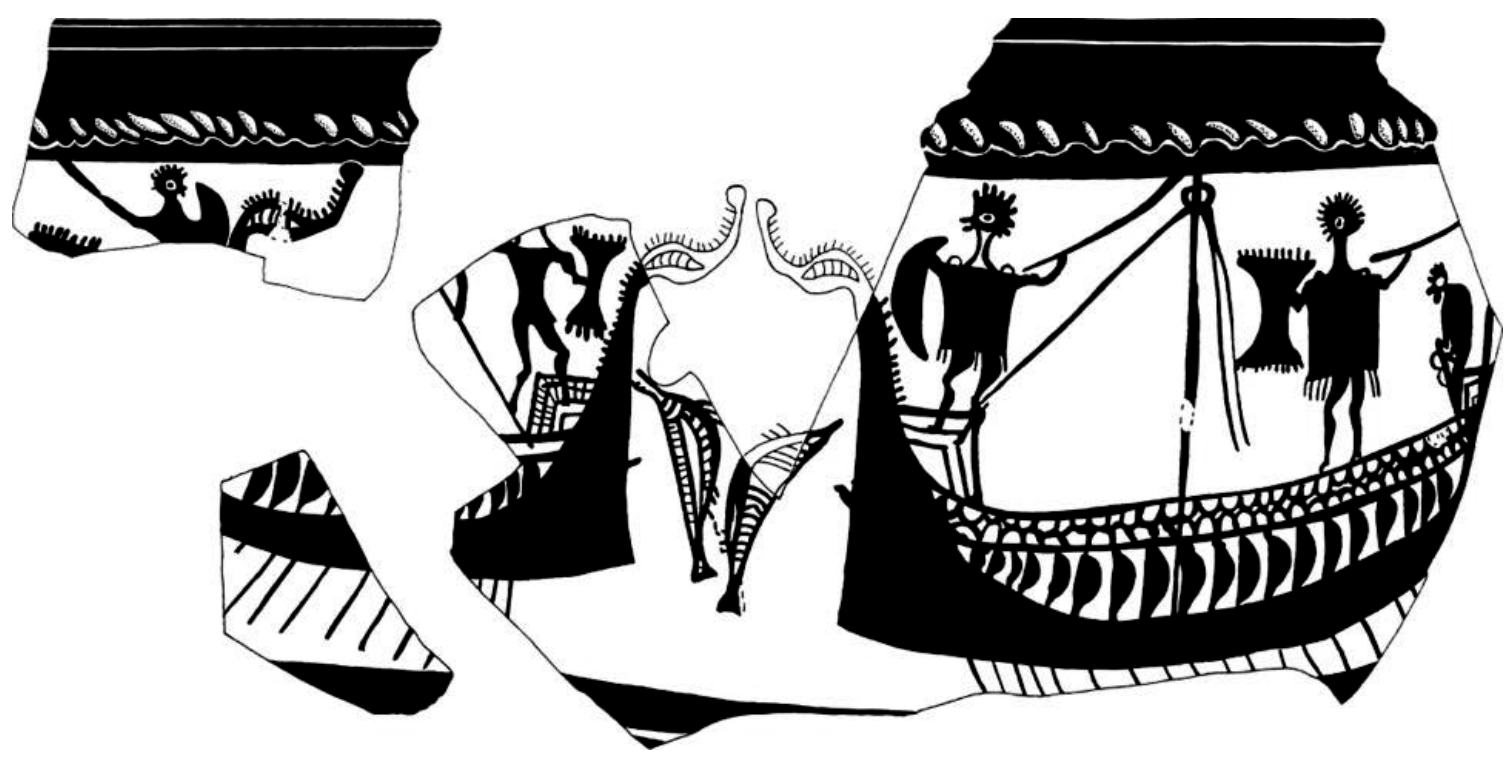

Fig. 4 LH IIIC Middle krater from Pyrgos Livanaton (Kynos) featuring a scene of warfare between hedgehog-helmed warriors. (Dakaronia \& Mpougia 1999, 23). 


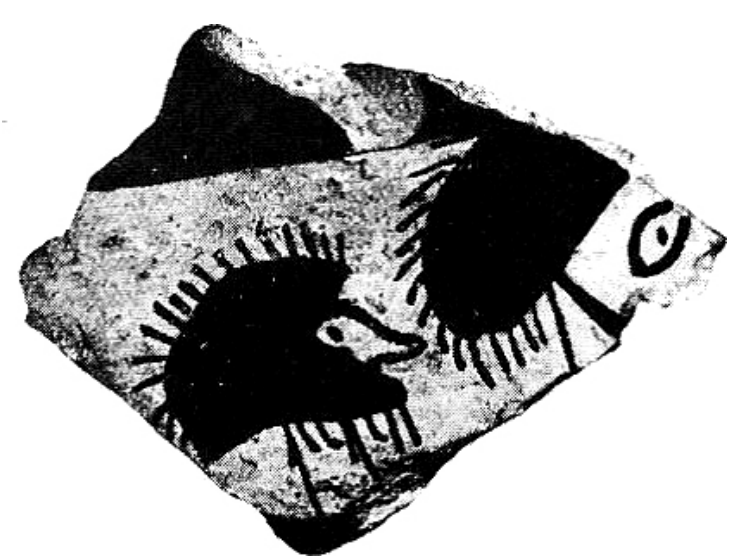

Fig. 4a Fragment of a LH IIIC Middle krater from Mycenae showing a hedgehog-helmed warrior and what may be an actual hedgehog. (Vermeule \& Karageorghis, 1982, pl. XI, 45).

hog (Dakoronia 1990, 119). A fragment of a LH IIIC Middle krater from Mycenae (fig. 4a) shows the similarity between hedgehog and helmet of that type and perhaps that piece suggests that this animal consist raw material for the construction of the specific type of helmet (Furumark 1941, 23742; Emanuel 2015, 63-65).

On another shred of Late Helladic 1llC from Kynos (Fig. 5) marines were light armed. They are holding two types of shields and javelins or swords as could be used at close-in combats on decks. Their helmets are of different type and, as we have mentioned above, its quite possible to have the first depiction of an archer on board.

\section{CONCLUSIONS}

From the limited finds above we understand that Bronze Age Greek marines played a decisive role in naval battles and landing operations. Except the cases of land warriors who used warships as transportation in order to move to theatre/ area of operations, marines should be trained to achieve their task as posteriors did so. The equipment of marines looks like following the typical hoplite armament: helmets, shields, spears, rapiers while there are also depictions with nude marines or with light armament. It raised also the issue of a marine's rudimentary training.

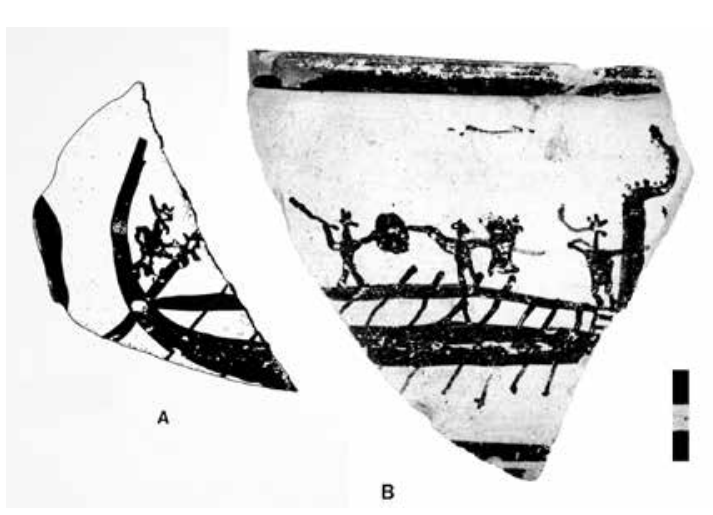

Fig. 5 LH IIIC Middle krater from Pyrgos Livanaton (Kynos). (Dakaronia 1996, 171).

From the available excavation finds the first depiction of marines could be from Middle Helladic period, around 1700BC, while first archers (Late Helladic IIIC) and slingers (Middle Helladic period) still leave space for more research.

Last but not least, the visual sources underline also the fact that warships do had deck (semidecked or partly decked) and were not undecked as has been misunderstood from Thucydides text.

\section{Acknowledgements:}

To Mr Spyros Bakas, Archaeologist (M. Sc.), for his kind support on this study.

$$
* * *
$$

Arheologija i prirodne nauke (Archaeology and Science) is an Open Access Journal. All articles can be downloaded free of charge and used in accordance with the licence Creative Commons - Attribution-NonCommercial-NoDerivs 3.0 Serbia (https://creativecommons.org/licenses/bync-nd/3.0/rs/.

Časopis Arheologija i prirodne nauke je dostupan u režimu otvorenog pristupa. Članci objavljeni u časopisu mogu se besplatno preuzeti sa sajta i koristiti u skladu sa licencom Creative Commons - Autorstvo-Nekomercijalno-Bez prerada 3.0 Srbija (https://creativecommons.org/licenses/bync-nd/3.0/rs/. 


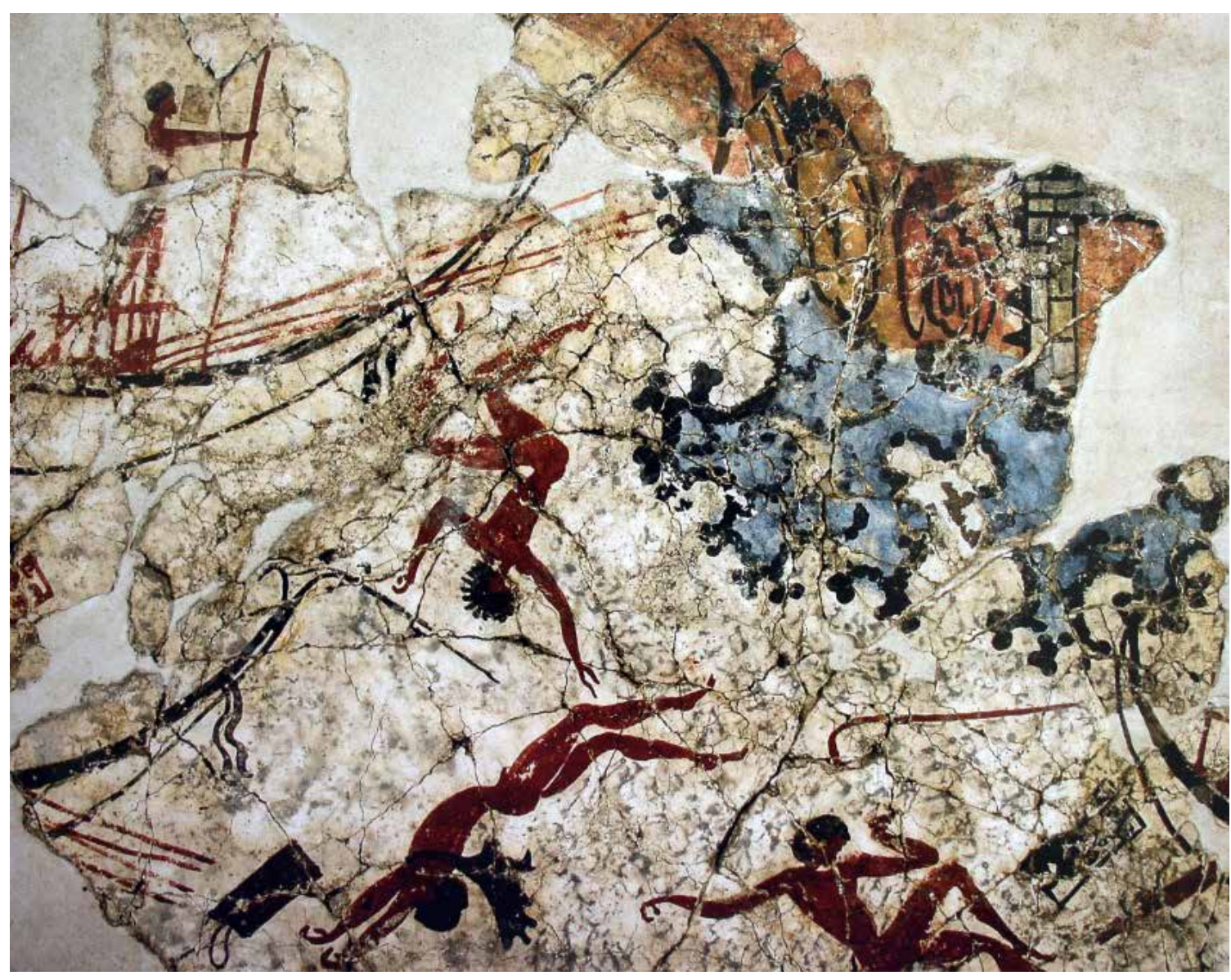

Fig. 6 Scene in the north Miniature Frieze (Middle Helladic period).

\section{BIBLIOGRAPHY}

\section{Bakas, S. 2014}

An insight view of the shooting methods of the archers of the Ancient Greek World 1400 BC400 BC, National Association of Archery for all, WTAOC Publishing, South Korea: 10-19.

\section{Bakas, S. 2016}

Composite bows in Minoan and Mycenaean warfare, Archaeological Journal "Syndesmoi" University of Catania, Sympozjum Egejskie. Proceedings of The 2nd Students' Conference in Aegean Archaeology: Methods- Researches Perspective, Institute of Archaeology, University of Warsaw, Poland, April 25 $5^{\text {th: }}$ 9-15.

\section{Basch, L. 1991}

Carenes egeennes à L'Age du Bronze, in: Thalassa. L'Egee Prehistorique et la Mer. Actes de la Troisieme Rencontre Egeenne Internationale de l' Universite de Liege. Calvi, 23-25 Avril 1990, Liege.

\section{Basch, L. 1996}

Notes sur l' éperon, TROPIS IV, Proceedings of the Fourth International Symposium on Ship Construction in Antiquity, Athens, August 29- September 1, 1991, (Athens: Harry Tzalas, Hellenic Institute for the Preservation of Nautical Tradition): 31-90.

\section{Brecoulaki, H. 2008}

An Archer from the Palace of Nestor: A New Wall-Painting Fragment in the Chora Museum, Hesperia: The Journal of the American School of Classical Studies at Athens, Vol. 77, No. 3: 376. 


\section{Charles, J. F. 1948}

The Marines of Athens, The Classical Journal, Vol. 44, n. 3: 181-188.

\section{Dakoronia, F. 1990}

War Ships on shreds of LHlllC from Kynos, Tropis II: 117-122.

Dakoronia, F. 1999

Represenation of Sea-Battles of Mycenaean shreds from Kynos, Tropis V: 119-128.

\section{Doumas, Ch. 1965}

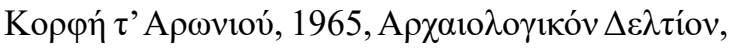
20: 53.

(Doumas, Ch. 1965

Korphí t'Aronioú, 1965, Arkhaioloyikón Deltíon, 20: 53.)

Emanuel, J. P. 2015

Black Ships and Fair-Flowing Aegyptus: Uncovering the Late Bronze-Early Iron Age Context of Odysseus' Raid on Egypt, Master's thesis, Harvard Extension School: 63-65.

Everson, T. 2006

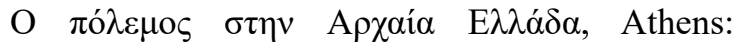

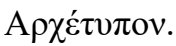

(Everson, T. 2006

O pólemos stin Arkhaía Elláda, Athens: Arkhétipon.)

\section{Furumark, A. 1941}

The Mycenaean Pottery: Analysis and Classification, Stockholm.

\section{Grguric, N. 2005}

The Mycenaeans c. 1650-1100 BC, Osprey Publishing Ltd.

Johnston, P. 1985

Ship and Boat models in Ancient Greece.

\section{Ioannidou, Ch. 2014}

Dictionary of Ancient Greek Naval Terms [in

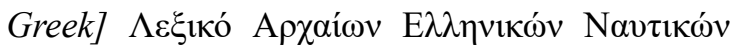
'O $\rho \omega v$, Athens: Historical Quest.

(Ioannidou, Ch. 2014

Dictionary of Ancient Greek Naval Terms [in Greek] Lexikó Arkhaíon Ellinikón Naftikón Óron, Athens: Historical Quest.)

\section{Ioannidou, Ch. 2016}

Trireme Tactics and Operational Environment in

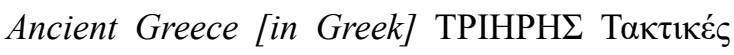

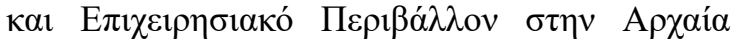
E $\lambda \lambda \alpha \dot{\alpha} \alpha \alpha$, Athens: Naval History Department/Hellenic Navy.

(Ioannidou, Ch. 2016

Trireme Tactics and Operational Environment in Ancient Greece [in Greek] TRIIRIS Taktikés kai Epikhirisiakó Perivállon stin Arkhaía Elláda, Athens: Naval History Department/Hellenic Navy.)

\section{Kelder, J. 2005}

The chariots of Ahhiyawa, N.S., tomes XLVIIIXLIX, Bucarest, 2005: 151-160.

Kirk, G. 1949

Ships on Geometric vases, BSA 44: 93-153.

\section{Kramer-Hajos, M. 2016}

Mycenaean Greece and the Aegean World: Palace and Province in the Late Bronze Age, Cambridge: Cambridge University Press.

\section{Lorimer, H. L. 1950}

Homer and the Monuments, Macmillan.

\section{Marinatos, S. 1933}

La Marine Creto-Mycenienne, BCH 57: 170-235.

\section{Mayor, A. 2006}

Greek Fire, Poison Arrows \& Scorpion Bombs

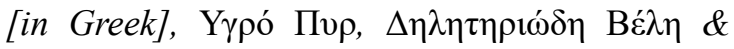

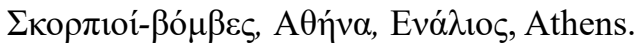
(Mayor, A. 2006 
Greek Fire, Pison Arrows \& Scorpion Bombs [in Greek], Igró Pir, Dilitiriódi Véli \& Skorpií-vómves, Athína, Enálios, Athens.)

\section{Nelson, H.H. 1943}

The Naval Battle Pictured at Medinet Habu, Journal of Near Eastern Studies, Vol. 2, No. 1: 40-55.

Tarlea A. 2005

Playing by the rules: Swords and Swordfighters in the Mycenaean Society, Dacia - Revue d'archéologie et d'histoire ancienne 48-49: 125-150.

\section{Vutiropulos, N. 1991}

The sling in the Aegean Bronze Age, Antiquity 65: 279-286.

\section{Wachsmann, S. 2009}

Seagoing Ships \& Seamanship in the Bronze Age Levant, Texas A\&M University Press.

\section{Wedde, M. 1999}

Decked vessels in early Greek ship architecture, TROPIS V: 505-526.

\section{Wood, A. 2012}

Warships of the Ancient World 3000-500 BC, Oxford: Osprey Publishing.

\section{REZIME \\ HELENSKE POMORSKE SNAGE U KASNOBRONZANOM PERIODU U GRČKOJ}

\section{KEYWORDS: GRČKI BRODOVI, POMORSKE SNAGE, KASNO BRONZANI PERIOD GRČKE.}

Arheološki nalazi iz perioda bronzanog doba pružaju veliki broj informacija koje se odnose na konstrukciju grčkih brodova. Nažalost, opisi ratnih brodova su vrlo retki. Pored toga, nedostatak prikaza pomorskih bitaka na ilustracijama i u istorijskim izvorima, stvara poteškoće u proučavanju pomorskih borbi. Ratnici na brodu, koji su činili jedan primitivan oblik pomorskog korpusa iz poznog bronzanog doba Grčke, pružaju otežavajuću, ali vrlo zanimljivu oblast za arheološka i istorijska istraživanja pomorskih bitaka iz perioda koji je prethodio formiranju antičke Helade. 